\title{
МЕТОДОЛОГІЯ ДОСЛІДЖЕННЯ ПРОБЛЕМАТИКИ ПРАВОВОГО ЗАБЕЗПЕЧЕННЯ СПЕЦІАЛЬНИХ ІНФОРМАЦЙНИХ ОПЕРАЦІЙ
}

\author{
ВЕРГОЛЯС Олександр Олександрович - кандидат юридичних наук, \\ старший викладач кафедри права, Мелітопольський державний педагогічний \\ університет імені Богдана Хмельницького, м. Мелітополь, Україна \\ https://orcid.org/0000-0002-9780-1298 \\ УДК 342.9 \\ DOI 10.32782/LAW.UA.2021.2.12
}

Метою дослідження було бормування розуміння та засад того, як необхідно підходити до визначення критеріїв та розуміння ступеня бормалізацї підготовки, проведення та підбиття підсумків від реалізаџї спеціальних інформаційних операџій. Під иас написання иієї роботи було використано майже весь спектр методологічних підходів дослідження, оскільки в залежності від того, що ставиться за мету, які інструменти та як протікає операчія, важливо визначити інструмент правового врегулювання інформачійних операчій.Методологія дослідження організачійно-правових $i$ теоретико-методологічних засад інбормаційно-правового забезпечення СІО становить систему методів (способів і прийомів), а також сукупність принципів, застосування яких уможливлюе одержання нових знань щодо організащї та проведення СІО. Зазначене дослідження базується на використанні комплексу загальнонаукових $i$ спечіальних методів, властивих дослідженням з інбормаційного права. Зокрема, застосовуються системноструктурний, бормально-логічний, порівняльно-правовий, історичний, діалектичний, моделювання, порівняльного аналізу, сочіологічний та статистичний методи, що дає змогу вивчити досліджувані об'єкт $i$ предмет, активно вплинути на них з метою зміни й удосконалення.

Ключові слова: інформачійна безпека, спеціальні інбормаційні операщій, стратегічні комунікацї, інформаційна система.
Постановка проблеми

Головна ідея та основні положення концепції дослідження відбиті в гіпотезі, що грунтується на припущенні, за яким належне інформаційно-правове забезпечення СIO на основі норм та принципів інформаційного права дозволить підвищити ефективність проведення СIO, що сприятиме забезпеченню національної безпеки України та досягненню нашою державою інформаційних переваг у реальних та потенційних інформаційних конфліктах, у т.ч. в ході гібридної війни. При цьому беззаперечним $є$ те, що саме методологія вважається головним орієнтиром наукового пошуку, надійним засобом встановлення істини в галузях науки.

Чималу увагу методологічним проблемам приділено в наукових працях О.Бандурки, А.Васильєва, Г.Гальперіна, В.Гоймана, В.Ісакова, Д.Керімова, Н.Нижник, І.Рассохи, С.Мосова, О.Скакун та багатьох інших учених. Водночас особливості розв’ язання наукової проблеми, зокрема проблематики інформаційно-правових засад СIO, вимагають певної методики та методів дослідження. Поняття “методологія” та поняття “метод” у деяких наукових школах вважають тотожними, хоча вітчизняна наука чітко розмежовує ці поняття. Так, у науковій літературі зустрічаються різні поняття терміна “методологія". Серед них найбільш розповсюджені філософські поняття, де методологія розглядається як філософське вчення про методи пізнання та практику, або перетворення дійсності. 
На думку О. Скакун, методологія - це система визначених теоретичних принципів, логічних прийомів, конкретних способів дослідження предмета науки. Теоретичні принципи - історія, єдність логічного й історичного. Аогічні прийоми - дедуктивний та індуктивний умовивід, аналіз і синтез, порівняння, узагальнення. Конкретні способи дослідження - інструменти пізнання, застосовувані для встановлення знання про досліджуваний предмет [1, с. 2]. В.Шейко та Н.Кушнаренко вважають, що у предмет загальної методології науки входять такі питання, як специфіка наукового пізнання в порівнянні 3 повсякденним мисленням, основні особливості і закономірності науково-пізнавальної діяльності, відношення емпіричного і теоретичного рівнів наукового дослідження, гіпотеза як форма розвитку науки, пояснення і передбачення як вихідні функції наукового мислення, загальні прийоми наукового дослідження - абстрагування, ідеалізація, моделювання, закон як форма наукового пізнання, природа, структура й функції наукової теорії закономірності їі формування і розвитку, взаємовідношення теорії і її емпіричного базису [2, с. 35]. У цілому доробки, відбиті у працях низки вчених, дають змогу дійти висновків, що поняття методології тлумачать у двох аспектах: 1) система певних способів і прийомів, які застосовують у певній сфері діяльності (наприклад, науці, політиці, мистецтві тощо); 2) вчення про цю систему, загальна теорія методу, теорія в дії.

Метою дослідження було формування розуміння та засад того, як необхідно підходити до визначення критеріїв та розуміння ступеня формалізації підготовки, проведення та підбиття підсумків від реалізації спеціальних інформаційних операцій.

Переходячи від узагальненого уявлення методології як науки про метод до більш конкретного розуміння іiї сутності, зазначимо, що науковцями виділяється кілька аспектів інтерпретації цього поняття. Зокрема, методологія розглядається як наука про метод або ж теорія методу, що розкриває його сутність, концептуально пояснюючи його пізнавальні, оцінні або практичні мож- ливості, разом з тим розглядає структуру, механізм, алгоритм, межі, переваги й недоліки методу. Однак, наукою дотепер не вироблена єдина теорія методу, а існує безліч різних теорій і концепцій. При цьому сутність методології зводиться до сукупності принципів, що є орієнтирами при побудові й здійсненні людської діяльності. Слід зауважити також, що до методології відносять усе, що можна розглядати як метод діяльності. До методології практичної діяльності поряд із принципами практики відносять теорії матеріальної цілеспрямованої людської діяльності, а також методи і конкретні прийоми їхнього здійснення. У методологію пізнавальної діяльності поряд із принципами пізнання входять теорії методів, власне методи пізнання, а також прийоми і правила пізнавальної діяльності, тобто все, що можна використовувати для одержання знань як метод. При цьому у дослідженні проблематики інформаційно-правових засад СІО методологічність наукового підходу є усвідомленим ставленням до засобів і передумов діяльності щодо формування, функціонування й удосконалення діяльності сектору безпеки і оборони країни [3] в аспекті проведення СIO на основі організаційних та правових засад. Тож у цілому методологія покликана виконувати дві основні функції: 1) отримання нового знання та подання цього знання у вигляді понять, критеріїв, законів, теорій, гіпотез; 2) організація використання нових знань у практичній діяльності. Тож завдяки правильно обраній методологічній системі способів і прийомів нам вдасться одержати нові знання щодо проблематики інформаційно-правових засад СІО. Своєю чергою, метод (грец. - шлях дослідження чи пізнання) - це спосіб організації практичного й теоретичного освоєння дійсності, зумовлений закономірностями розвитку об'єкта [4]. Це також сукупність прийомів чи операцій практичного або теоретичного освоєння дійсності, підпорядкованих вирішенню конкретного завдання. Відмінність між методом і теорією має функціональний характер: формуючись як теоретичний результат попереднього дослідження, метод виступає вихідним пунктом та умовою майбутніх досліджень [107, с. 23]. 


\section{Адміністративне право}

Отже, під методом у нашому випадку слід розуміти сукупність конкретних прийомів і способів пізнання, перетворення чи оцінки дійсності. Якщо під методологією зазвичай розуміють сукупність знань про методи, то під методом - певну сукупність прийомів, способів та засобів досягнення визначеного результату чи досягнення мети, тобто вирішення поставлених завдань.

Відтак метод є складовою методології. У роботі використовувалася сукупність теоретичних та емпіричних методів дослідження, що властиві науковим розробкам у сфері інформаційного права та забезпечення національної безпеки. Так, застосування діалектичного методу надало можливість визначити зміст та встановити специфіку інформаційно-правового забезпечення СIO в сучасних умовах, вивчити зарубіжний досвід у цій сфері. За допомогою системно-структурного методу було досліджено недоліки нормативно-правового регулювання та прикладні проблеми інформаційно-правового забезпечення СIO в діяльності українських спецслужб. Метод правового аналізу дав змогу охарактеризувати правові норми відповідних галузей права, що стосуються питань інформаційної безпеки та проведення CIO, а також визначити шляхи удосконалення нормативної бази у відповідній сфері. Використання формально-логічного методу сприяло формуванню понятійного апарату дослідження, дозволило сформулювати відповідні пропозиції з внесення змін до актів чинного законодавства, якими регламентовано питання проведення СIO, а також сформулювати висновки цієї роботи. Порівняльно-правовий та історичний методи дозволили дослідити історичну ретроспективу становлення інформаційно-правового забезпечення CIO та провести узагальнення досвіду інших країн з питань проведення СIO. За допомогою методу моделювання визначено та оптимізовано модель СІО. На підставі використання соціологічного та статистичного методів визначено актуальні підходи до сутності інформаційної безпеки, досліджені стан та властивості інформаційно-правового забезпечення СIO в сучасних умовах. Зокрема, застосування соціологічного і соціотехнічного підходу до інформа- ційної безпеки в умовах глобалізації на основі тензорної методології складних систем полягає в тому, що інформаційне протиборство розглядається на основі концепції специфічної інформаційної реальності, що обумовлена не лише розвитком технологій, але й глобальною фінансово-економічною кризою, та характеризується загостренням протиріч між динамічними турбулентними процесами глобалізації й зростанням значущості національної держави та ії безпеки в інформаційному протиборстві. Крім того, тензорна методологія дозволяє обгрунтовано пов'язувати процес і структуру, що набуває особливого значення для організації та проведення СIO (складової системи стратегічних комунікацій) при розумінні інформації як комунікації. Застосування тензорної методології також дозволяе представляти будь-яку систему 3 низки аналогічних систем як проєкція узагальненої системи. «Якщо розглядати узагальнену систему як тензор, а конкретні системи цього класу - як iї проєкція в окремих системах координат, то можна використовувати головне для тензорного методу», а саме - «необхідно обрати одну систему і використати їі як еталонну систему координат, приводячи описи (рівняння) інших систем до опису в термінах цього еталону (моделювати)» [180, с.12]. Тензорна методологія носить міждисциплінарний характер, тому що вона дозволяє виступати в якості єдиного, «наскрізного підходу» при вивченні складних систем різної природи. Система правил використання методів, прийомів та операцій становить суть методики дослідження. Набір конкретних методів дослідження визначається характером фактичного матеріалу й метою дослідження. Методи є упорядкованою системою, де їхнє місце визначене відповідно до конкретного етапу дослідження, використання технічних прийомів i проведення операцій з теоретичним і фактичним матеріалом у певній послідовності. Нормативноправовою основою роботи стали як Конституція та законодавство України, закордонних країн, міжнародно-правові акти, що регулюють питання національної та державної безпеки, інформаційного протиборства та характеризують інформаційно-правові заса- 
ди CIO. Слід також зауважити, що кожна складова в структурі методології має своє особливе призначення, і одночасно несе в собі системотвірну функцію. Іншими словами, на сучасному етапі розв'язання питань ефективності КРЗ потребує застосування синергетичного підходу, зокрема одночасного використання різних методів досліджень. Для синергетики властивий підхід щодо виявлення одного, головного фактору, який здійснює основний вплив на процес руху до “порядку” і якому підкорені всі інші зміни. Цей фактор умовно називається “параметр порядку”, що не дозволяє безпосередньо керувати розвитком системи, тобто переводити її в інший, заздалегідь визначений стан. Оскільки синергетика має справу з конкретними системами (у юриспруденції - це правова система, а її однією з мікроструктур є правовідносини, у нашому випадку пов'язані 3 інформаційно-правовим забезпеченням СIO), то слід констатувати, що “параметром порядку” цієї мікроструктури вони й мають бути. Відповідно, найкращим варіантом формування теоретичних, організаційних та правових засад СIO буде виділення відповідного фрагменту дійсності, який має значення і викликає інтерес у суб'єктів права. Своєю чергою, основні засади будь-якої діяльності, зокрема й проведення СIO, визначають принципи, що формують загальні напрями та правила в конкретній сфері суспільних відносин. До загальнонаукових принципів дослідження належать: історичний, термінологічний, функціональний, системний, когнітивний, метод моделювання тощо. Історичний принцип дає змогу дослідити виникнення, формування і розвиток теорії та практики інформаційно-правового забезпечення СIO, у хронологічній послідовності з метою виявлення внутрішніх та зовнішніх зв'язків, закономірностей та суперечностей. У межах історичного підходу активно застосовується порівняльно-історичний метод - сукупність пізнавальних засобів, процедур, які дозволяють виявити схожість і відмінність між організацією діяльності в різних галузях соціальних відносин та діяльністю щодо інформаційно-правового забезпечення СIO, визначити їхню генетичну спорідненість (зв’язок за походженням), загальне й специфічне в їхньому розвитку. В основі загальнонаукового принципу історичного підходу лежить діалектичний закон руху як способу існування матерії та свідомості. Врахування цього закону у поєднанні з принципом системності є обов'язковою вимогою наукового пошуку. У цьому контексті при історичному підході до інформаційно-правового забезпечення CIO на перший план виступають закономірності становлення цього напряму діяльності у забезпеченні національної безпеки, що застерігає від суб'єктивізму й однобічного підходу, забезпечує системність дослідження. Слід наголосити, що природа науки та ії методології принципово системна, відтак у загальнонауковій методології широко застосовується системний підхід, який для дослідження інформаційно-правового забезпечення CIO грає визначальну роль. Сутність його полягає в комплексному дослідженні великих і складних об'єктів (систем), вивченні їх як єдиного цілого 3 узгодженим функціонуванням усіх елементів і частин. Визначальною основою дослідницького етапу конкретнонаукової методології є сукупність ідей або специфічних методів юридичної науки, які 6 базою для розв'язання конкретної дослідницької проблеми та на які ми опираємось в нашому дослідженні. Конкретна наукова методологія потребує також звертання до загальновизнаних концепцій провідних учених. Наші пошуки методологічних засад дослідження здійснювалися за такими напрямами: історіографія, у межах якого було проведено вивчення наукових праць провідних учених як $з$ теорії безпекознавства, так і в галузях міжнародного, інформаційного, військового, кримінального, адміністративного права тощо, які застосовували загальнонаукову методологію для вивчення конкретного напрямку організації діяльності у сфері правозастосування; узагальнення ідей науковців, які безпосередньо вивчали проблеми правозастосування у зазначених галузях; проведення досліджень специфічних підходів для розв'язання наукових питань у сфері практичної діяльності структур сектору безпеки і оборони, які не лише розробили, а й реалізували на практиці свої ідеї; аналіз концеп- 


\section{Адміністративне право}

цій у правовій сфері міжнародної діяльності та зарубіжних учених і практиків. Прикладним показником істинності наукової інформації, як відомо, є практика. Однак практику не можна розуміти лише як суто емпіричний досвід сьогоднішнього дня. Більш широке розуміння практики включає насамперед суспільно-історичну практику розвитку людського суспільства в цілому. Проблема достовірності результатів наукової роботи може бути вирішена тільки в процесі одержання достовірного знання про досліджуваний об'єкт, де всі етапи аналізу і прогнозування представляють органічні складові частини єдиного цілісного пізнавального процесу. ШАях пізнання певного процесу може бути традиційним: від аналізу конкретних явищ до їх абстракції - поняття, а від них до тієї реальної дійсності, з якої починалося пізнання. На сучасному рівні розвитку юридична практика та наука накопичили широкий масив наукових знань щодо різноманітних юридичних фактів стосовно інформаційно-правового забезпечення CIO, а також достатній теоретичний та методологічний потенціал цих знань, які сьогодні потребують узагальнення з позиції виникнення, розвитку, функціонування, призначення і сутності правових явищ. Наукове дослідження теоретичних, правових та організаційних засад інформаційно-правового забезпечення СIO як цілісного й гармонійного явища потребує застосовування всієї сукупності пізнавальних засобів, що вироблені наукою та практикою. Загальним при цьому виступає діалектичний метод, основу якого складає зв'язок теорії і практики, взаємодія зовнішнього і внутрішнього, адже діалектичний закон загального зв'язку явищ лежить в основі загальнонаукового принципу системності, що поширився на норми права та правозастосування. 3 іншого боку, правові норми формулюють умови переходу суспільних відносин в інший якісний стан правові відносини. Тут наявна загальна закономірність єдності форми і змісту, переходу кількості в якість [5, с. 68]. Враховуючи викладене, цю єдність 3 їі кількісно-якісною характеристикою складають цілі, завдання, функції, принципи та методи інформаційноправового забезпечення СIO та наявність відповідного організаційного механізму їх проведення. Як бачимо, дослідження теоретичних, правових та організаційних засад інформаційно-правового забезпечення СIO, як процес пізнання, що протікає відповідно до загальних законів діалектики, має свою специфіку, обумовлену особливостями об’єкта пізнання і правозастосовної діяльності. Разом 3 тим, потрібно враховувати, що юридичне пізнання спирається на дослідження філософських, спеціально-юридичних та прикладних наук. Вирішення завдань інформаційно-правового забезпечення СIO має здійснюватися із обов'язковим застосуванням аксіологічного підходу як гуманістичної та моральної основи. Аксіологічний підхід до організації діяльності полягає в тому, що його учасники, складаючи частину правовідносин, $\epsilon$ внутрішньою структурою. Він має важливе значення для суб'єкта правовідносин, вирішуючи певні розбіжності. Аксіологія у вивченні права має важливе наукове, практичне та моральне значення, адже це загальна стратегія дослідження, що визначає розгляд правозастосування в інформаційно-правовому забезпеченні СІО крізь призму відповідності певним цінностям, що можуть забезпечуватись правом та бути його основою. Як уже зазначалося, емпіричні проблеми у нашому дослідженні вирішуються насамперед з урахуванням матеріалів, даних та здобутків вітчизняних науковців та практиків. Проте, пошук шляхів розв'язання цих проблем не можливий без порівняльних досліджень та використання світових доробок у теорії та методології організації діяльності іноземних спеціальних служб з урахуванням особливостей правових систем держав їх належності. Порівняльно-правовий аспект дослідження особливо актуалізується в умовах реалізації євроінтеграційних прагнень України. Водночас не слід забувати, що цей аспект базується на тому, що правові системи світу демонструють розмаїття фактологічних передумов національного правового регулювання, що визначається способами юридичної ідентифікації форм, методів діяльності, їх “виділення" з поведінки, життевих ситуацій. Звідси, врахування особливостей іноземного досвіду проведення СIO не 
може бути безумовним, адже організаційні та правові засади проведення СІО у будьякій країні формуються в умовах саме іiї геополітичних і правових реалій, які не $\epsilon$ характерними для України. Таким чином, методологія цього дослідження, яку обрано 3 урахуванням його мети, завдань, об'єкта і предмета, передбачає інтегроване використання загальнонаукових та спеціальних методів дослідження, що застосовуються у філософській та управлінсько-правовій науці. За застосування системного підходу, у процесі дослідження об'єкт дослідження уявно поділяється, виокремлюються його елементи, його зовнішні і внутрішні зв'язки, окреслюється його структура і висувається припущення про механізм його функціонування та розвитку. Кожну конкретну науку, діяльність, об'єкт можна розглядати як певну систему, що має множину взаємопов'язаних елементів, компонентів, підсистем, визначені функції, цілі, склад, структуру. До загальних характеристик системи відносять: цілісність; структурність; взаємозв'язок із зовнішнім середовищем; ієрархічність; цілеспрямованість; самоорганізацію. У тісному зв'язку із системним підходом також широко використовувався структурно-функціональний метод. Цей метод передбачає розгляд будь-якого явища як системного 3 обов'язковим аналізом функцій взаємодіючих елементів. У дослідженні теоретичних, правових та організаційних засад проведення CIO та їх інформаційного забезпечення використовувалося два основні рівні наукового пізнання: емпіричний і теоретичний. Ці рівні зумовлюють формування в межах методів, використовуваних нами, як теоретичних, так і емпіричних процедур і прийомів, систематичне застосування яких приводить до досягнення поставленої мети. Емпіричні методи пізнання $є$ не лише основою для закріплення теоретичних передумов, а й часто становлять предмет нового відкриття, нового наукового дослідження. Характерною особливістю емпіричного пізнавального рівня $\epsilon$ те, що він містить безпосередній контакт дослідника 3 предметом дослідження; дає знання зовнішніх, видимих зв'язків між формою та змістом їх діяльності. Кінцевою метою емпіричного пізнання 6 фіксація повторення явищ, що приводить до обгрунтованих узагальнень. Емпіричні знання у нашому дослідженні спираються на емпіричні факти практики шляхом вивчення навчальної, навчально-методичної літератури, публікацій у 3МІ, аналітичних матеріалів тощо. Використання результатів практичної діяльності - це найбільш загальний емпіричний метод пізнання, який не лише включає спостереження й оцінювання, а й здійснює трансформацію, зміну об’єкта дослідження тощо. Своєю чергою, теоретичним рівнем пізнання є, по-перше, логічне узагальнення практичного досвіду управління; по-друге, протилежні емпіричним методам наукові методи пізнання. Теоретичне знання має загальний і необхідний характер, містить відомості про внутрішні закономірності спостережуваних явищ. На цьому рівні можна отримати певні знання не тільки за допомогою досвіду, але й абстрактного мислення. У теорії пізнання превалює застосування способу сходження від абстрактного до конкретного як метод дослідження, при якому науковий пізнавальний процес веде від менш змістовного до більш змістовного знання. У теоретичному дослідженні, де в основному використовується здатність суб'єкта до абстрактного мислення, будь-яке поняття асоціюється 3 певною сукупністю сприйнять і наочних образів. Тобто емпіричне пізнання теоретично навантажене, а будь-яка абстрактна теорія має емпіричну інтерпретацію. Головним пізнавальним завданням емпіричного рівня $\epsilon$ опис явищ, тоді як на теоретичному рівні таким завданням $\epsilon$ пояснення явищ, що вивчаються. Співвідносно відрізняються й методи, спрямовані на отримання цих типів знань. На емпіричному рівні пізнання основними методами $є$ спостереження, вимірювання, експеримент, порівняння, індуктивне узагальнення. На теоретичному рівні пізнання використовуються такі методи, як аналіз, синтез, індукція, дедукція, аналогія, гіпотеза тощо [6, с. 36-37]. При цьому нами враховано, що з позиції сфери застосування загальні методи наукового пізнання, на відміну від спеціальних, використовуються в дослідницькому процесі в різних галузях науки. Вони умовно поділяються на три ве- 


\section{Адміністративне право}

ликі групи: методи емпіричного дослідження (спостереження, порівняння, вимірювання, експеримент); методи, що використовуються як на емпіричному, так і на теоретичному рівнях дослідження (абстрагування, аналіз і синтез, індукція і дедукція, моделювання та інші); методи або методологія, що використовуються на теоретичному рівні дослідження (сходження від абстрактного до конкретного, системний, структурно-діяльнісний підхід) [2, с. 25]. Так, теоретикоприкладна частина дослідження здійснювалась із застосуванням комплексу загальнонаукових методів:

- індукції та дедукції - для зіставлення окремих наукових понять і категорій (інформаційна безпека, інформаційна війна, інформаційні операції тощо);

- аналізу та синтезу - 3 метою визначення сутності та змісту інформаційно правових засад CIO в сучасних умовах, оцінки вітчизняного та іноземного досвіду в цій сфері, формулювання правових та організаційних засад удосконалення інформаційно-правового забезпечення СIO;

- аналогії та компаративістики - для поглибленого дослідження теоретичних, організаційних та правових засад проведення CIO та їх інформаційного забезпечення в Україні та закордонних державах, вироблення шляхів оптимізації інформаційноправового забезпечення CIO;

- тлумачення - для аналізу та розкриття змісту основних категорій інформаційного права, які характеризують поняттєво-категоріальний апарат дослідження.

- логіко-семантичного методу - для уточнення поняттєвого апарату, з'ясування сутності процесу інформаційно-правового забезпечення CIO.

Зі спеціальних методів під час дослідження використано:

- історичний - для розгляду становлення інформаційно-правових засад CIO та наукових поглядів у зазначеній сфері;

- системно-структурний - для аналізу стану інформаційно-правових засад CIO на рівні міжнародного та національного законодавства як єдиної системи;

- порівняльно-правовий - при аналізі норм галузей права України, закордонно- го законодавства, міжнародних документів про забезпечення інформаційної та національної безпеки ;

- структурно-функціональний - для дослідження системного взаємозв'язку та взаємодії суб'єктів проведення СІО, а також стадій проведення СІО як елементів єдиної системи;

- соціологічний і статистичний - у процесі вивчення кількісних та якісних параметрів, що вказують на необхідність покращання інформаційно-правового забезпечення СIO, характеризують його стан, процес забезпечення національної безпеки в ціломy;

- прогнозування - 3 метою формулювання пропозицій щодо удосконалення інформаційно-правового забезпечення CIO.

\section{Висновки}

Методологія дослідження організаційно-правових і теоретико-методологічних засад інформаційно-правового забезпечення СIO становить систему методів (способів і прийомів), а також сукупність принципів, застосування яких уможливлює одержання нових знань щодо організації та проведення CIO. Зазначене дослідження базується на використанні комплексу загальнонаукових і спеціальних методів, властивих дослідженням 3 інформаційного права. Зокрема, застосовуються системно-структурний, формально-логічний, порівняльно-правовий, історичний, діалектичний, моделювання, порівняльного аналізу, соціологічний та статистичний методи, що дає змогу вивчити досліджувані об'єкт і предмет, активно вплинути на них 3 метою зміни й удосконалення. Особливу роль у дослідженні відіграє тензорна методологія, яка дозволяє обгрунтовано пов'язувати процес і структуру, що має особливе значення для проведення СIO як складової системи стратегічних комунікацій. Застосування тензорної методології також дозволяє поширити на СIO закономірності здійснення стратегічних комунікацій. Це забезпечує єдність методів, практичної діяльності й теорії, емпіричних і наукових знань. 


\section{Аітература}

1. Скакун О. Ф. Теорія держави і права: підручник / О. Ф. Скакун - Харків: Консум, 2000. - 2 с. Транслітерація: Skakun O. F. Teoriya derzhavi i prava: pidruchnik / O. F. Skakun - Kharkiv: Konsum, 2000. - 2 s.

2. Шейко В. М. Організація та методика науково-дослідницької діяльності: підручник: підручник / В. М. Шейко - Київ: Знання-Прес, 2002. - 25 с. Транслітерація: Sheyko V. M. Orhanizatsiya ta metodika naukovo-doslidnits 'koyi diyal 'nosti: pidruchnik: pidruchnik / V. M. Sheyko - Kiyiv: Znannya-Pres, 2002. - 25 s.

3. Про національну безпеку України // Верховна Рада України [Веб-сайт]. - URL: https://zakon.rada.gov.ua/laws/ show/2469-19 (дата звернення 09.04.2019 (дата звернення: 05.07.2021). Транслітерація: Pro natsional’ nu bezpeku Ukrayini // Verkhovna Rada Ukrayini [Veb-sayt]. - URL: https://zakon.rada.gov. ua/laws/ show/2469-19 (data zvernennya 09.04.2019 (data zvernennya: 05.07.2021).

4. Методологія наукових досліджень 3 державного управління: хрестоматія; за ред. За заг. ред. д-ра політ. наук К.О. Ващенка. . - Київ: НАДУ, 2014. - 180 с. Транслітерація: Metodolohiya naukovikh doslidzhen` z derzhavnoho upravlinnya: khrestomatiya; za red. Za zah. red. d-ra polit. nauk K.O. Vashchenka. . - Kiyiv: NADU, 2014. - 180 s.

5. Андрій М. 3. Методологічні та теоретичні основи пізнання юридичних фактів : монографія / М. 3. Андрій - Київ: Свропейський університет, 2011. - 68 с. Транслітерація: Andriy M. Z. Metodolohichni ta teoretichni osnovi piznannya yuridichnikh faktiv : monohrafiya / M. Z. Andriy - Kiyiv: Yevropeys 'kiy universitet, 2011. - 68 s.

6. Створене посилання: Фареник С. А. логіка і методологія наукового дослідження: науоково-методологічний посібник / С. А. Фареник - Київ: УАДУ, 2000. - 340 c. Транслітерація: Farenik S. A. Lohika i metodolohiya naukovoho doslidzhennya: nauokovo-metodolohichniy posibnik

S. A. Farenik - Kiyiv: UADU, 2000. - 340 s.
The main idea and the main provisions of the research concept are reflected in the hypothesis based on the assumption that proper information and legal support of SIO on the basis of norms and principles of information law will increase the effectiveness of SIO, as well as potential information conflicts, including in the process of hybrid warfare. At the same time in the study of information and legal principles of SIO methodological scientific approach is a conscious attitude to the means and prerequisites for the formation, operation and improvement of the security and defense sector in terms of conducting SIO on the basis of organizational and legal principles. The work used a set of theoretical and empirical research methods inherent in scientific developments in the field of information law and national security. Thus, the application of the dialectical method provided an opportunity to determine the content and establish the specifics of information and legal support of SIO in modern conditions, to study foreign experience in this field. With the help of the system-structural method the shortcomings of normative-legal regulation and applied problems of information-legal support of SIO in the activity of Ukrainian special services were investigated. The methodology of research of organizational-legal and theoretical-methodological bases of informationlegal support of SIO is a system of methods (methods and techniques), as well as a set of principles, the application of which allows to obtain new knowledge about the organization and conduct of SIO. This study is based on the use of a set of general and special methods inherent in the study of information law. In particular, system-structural, formal-logical, comparative-legal, historical, dialectical, modeling, comparative analysis, sociological and statistical methods are used, which allows to study the studied object and subject, to actively influence them to change and improve. A special role in the study is played by the tensor methodology, which allows to reasonably link the process and structure, which is of particular importance for the SIO as part of a system of strategic communications. The application of the tensor methodology also allows to extend to the SIO the laws of strategic communications. This ensures the unity of methods, practical activities and theory, empirical and scientific knowledge.

Keywords: information security, special information operations, strategic communications, information system. 